\title{
Verem Așısı Uygulayan Ülkelerin Bireyleri SARS-CoV-2 Virüsünün Yol Açtığı Enfeksiyona Karşı Daha Dirençli Olabilir mi?
}

\author{
Could Individuals From Countries Using BCG Vaccination Be Resistant to SARS-COV-2 Induced \\ Infections?
}

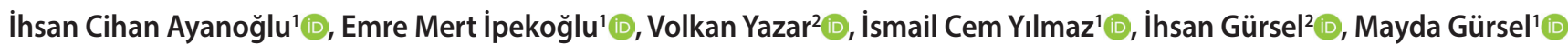

'Orta Doğu Teknik Üniversitesi, Biyolojik Bilimler Bölümü, Ankara

${ }^{2}$ Bilkent Üniversitesi, Moleküler Biyoloji Bölümü, Ankara

\section{Correspondence: \\ Mayda Gürsel \\ Orta Doğu Teknik Üniversitesi, Biyolojik \\ Bilimler, Ankara, Turkey \\ E-mail: mgursel@metu.edu.tr}

Received: Apr 28, 2020

Accepted: Apr 29, 2020

https://doi.org/10.25002/tji.2020.1250

(C)2020 Turkish Journal of Immunology

Available online at

http://www.turkishimmunology.org

\section{Öz}

SARS-CoV-2 vakalarının yetersiz sağlık sistemine sahip ülkelerde beklenenin altında olması kafalarda soru ișareti yaratmaktadır. Burada biz farklı ülkelerin benimsediği verem (BCG) aşısı politikalarındaki ve aşılamadaki suş tercihlerindeki farklılıkların SARS-CoV-2'nin bulaşma modeli ve/veya COVID-19 ile ilişkilendirilen hastalık ve ölüm oranlarını etkileyebileceği hipotezini öne sürmekteyiz. Ayrıca SARS-CoV-2'ye özgü bir aşı geliştirilene kadar, enfeksiyona yakalanma riski yüksek olan popülasyonların BCG aşısı ile bağışıklanması ile yeni korona virüse karşı özgül olmayan heterolog bir koruma sağlanabileceğini öne sürmekteyiz. İncelemelerimiz sonunda BCG aşısı kullanan ülkeler arasında en iyi COVID-19'dan korunma sağlayanların özellikle Grup I tipi BCG aşılaması uygulayan ülkeler olduğunu ortaya çıkarmaktadır. Bunların arasında ise Rusya suşunu kullanan ülkelerin diğer BCG aşısı kullanan ülkelerden daha da iyi korunma düzeyi gösterdikleri anlaşılmaktadır.

Anahtar Sözcükler: BCG, COVID-19, SARS-CoV-2 infeksiyonları, korunma

\section{Abstract}

The lower than expected number of SARS-CoV-2 cases in countries with fragile health systems is puzzling. Herein, we hypothesize that BCG vaccination policies and vaccine strain preferences adopted by different countries might influence the SARS-CoV-2 transmission patterns and/or COVID-19 associated morbidity and mortality. We also postulate that until a specific vaccine is developed, SARS-CoV-2 vulnerable populations could be immunized with BCG vaccines to attain heterologous nonspecific protection from the new coronavirus. In the lights of our investigations the most resistant countries appear to be the ones using Group I BCG strain. Within these countries, however, those who employs Russian strain is even more protected against COVID-19 infection.

Keywords: BCG, COVID-19, SARS-CoV-2 infections, protection

\section{Giriş}

Dünya Sağlık Örgütü (DSÖ) Genel Yöneticisi Tedros Adhanom Ghebreyesus Ocak ayındaki açıklamasında COVID-19 salgınının yetersiz sağlık sistemine sahip ülkelere sıçramasının en büyük endişesi olduğunu dile getirmişti. Hindistan, Filipinler, Sri Lanka, Kamboçya, Tayland, Vietnam ve Nepal gibi ülkelerde ilk COVID-19 vakaları Ocak ayında rapor edilmesine rağmen geçen süre zarfında bu ülkelerde enfeksiyonun popülasyon geneline yayılımı henüz raporlanmamıştır. Hatta makul beklentilerin ve tahminlerin aksine DSÖ 13 Mart 2020'de dünyanın geri kalanının toplamından daha fazla vakanın görüldüğü Avrupa’nın pandeminin yeni merkez üssü olduğunu ilan etmişti. ${ }^{[1]}$ Yeni koronavirüs salgınının daha ortasında olduğumuzdan dolayı bu durum gelecek günlerde bariz bir şekilde değişebilecek olmasına rağmen, sağlık sistemi yetersiz ve gelir düzeyi düşük ülkelerin orantısız olarak düşük vakalar rapor etmesi gizemini korumaktadır. Biz farklı ülkelerin benimsediği verem (BCG) aşısı politikalarındaki ve aşılamadaki suş tercihlerindeki 
farklılıkların SARS-COV-2'nin bulaşma modeli ve/veya COVID-19 ile ilişkilendirilen hastalık ve ölüm oranlarını etkileyebileceği hipotezini öne sürmekteyiz.

Normalde bir aşı belli bir patojene özgü efektör mekanizmaları tetikleyerek o patojene özgü koruma sağlar. Fakat bazı canlı zayıflatılmış aşılar sadece belirli bir patojene karşı değil başka alakasız patojenlere karşı koruma sağlayabilmektedir. ${ }^{[2]} \mathrm{Bu}$ bağlamda Mycobacterium bovis bakterisinin zayıflatılmış suşu olan Bacillus CalmetteGuerin (BCG) aşısının da bazıları akut solunum enfeksiyonlarına neden olan patojenler olmak üzere bazı başka ilgisi olmayan patojenlere karşı koruma sağladığı bilinmektedir. $^{[2-8]}$ BCG aşılamasının sağladığı spesifik olmayan korumanın arkasındaki mekanizmanın ilk kez Netea ve arkadaşları tarafından öne sürülen ${ }^{[9]}$ eğitilmiş bağışıklık konsepti olduğu düşünülmektedir. Bu konsept çerçevesinde eğitilmiş bağışıklığı tetikleyen ajanlar kemik iliğindeki hematopoetik kök hücreler ve multipotent öncül hücrelerde epigenetik ve metabolik değişikliklere yol açarak bu hücrelerin yeniden programlanmasına neden olmakta ve yeniden programlanma neticesinde

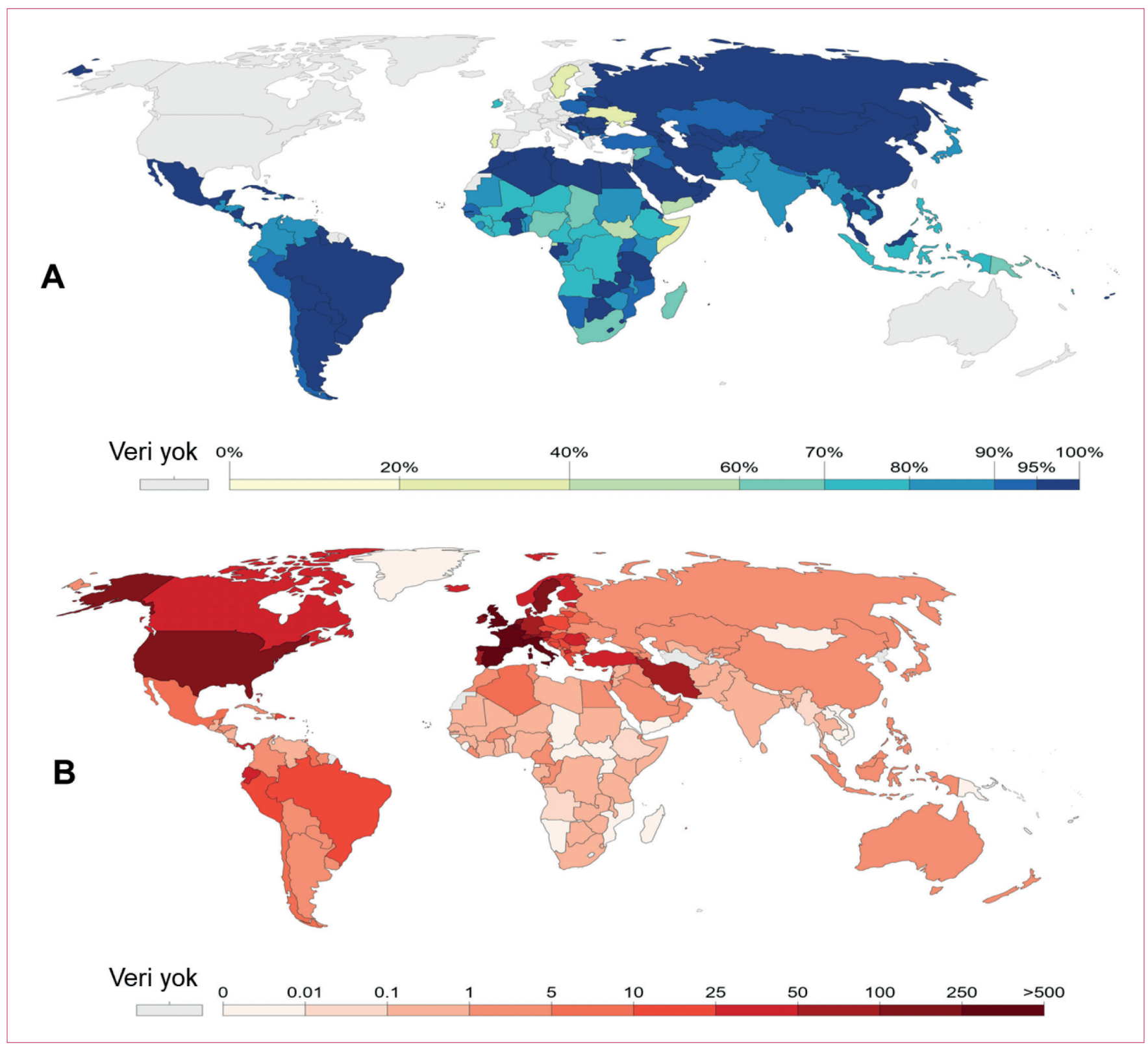

Şekil 1. A. 2015 DSÖ verilerine göre bir yaşındaki bebeklerin ülkelere göre verem (BCG) aşısı yapılma yüzdeleri. (https://ourworldindata.org/ grapher/bcg-immunization-coverage-for-tb-among-1-year-olds) B. Toplam doğrulanmış COVID-19 kaynaklı ölümler/milyon nüfus. (https:// ourworldindata.org/grapher/total-covid-deaths-per-million [En son 22 Nisan 2020 tarihinde güncellenen versiyon.]) 
doğal bağışıklık hücreleri bir patojenle karşılaştığında çok daha güçlü bir immünolojik yanıt vermektedir. ${ }^{[9-10]}$ BCG aşılaması özelinde bir örnek vermek gerekirse: randomize edilmiş, plasebo kontrollü bir insan çalışmasında bu aşılamanın monositlerde yeniden programlanmaya neden olarak sarı humma virüsünün zayıflatılmış aşı suşuna karşı koruma sağladığı gösterilmiştir. ${ }^{[11]}$

Tüm bu bilgilere dayanarak ulusal BCG aşılama programlarına devam eden ülkelerin, hiç ulusal BCG aşısı programı uygulamamış veya ulusal programı durdurmuş ülkelere kıyasla yeni koronavirüs salgınını daha iyi kontrol altına alabileceğini öne sürmekteyiz. Şekil 1'de BCG aşısının günümüzde uygulanmadığı ülkelerde, COVID-19 kaynaklı ölüm/milyon değerlerinin diğer ülkelerden yüksek olduğu eğilimi gözlemlenmektedir.

Her ülke pandeminin değişik safhalarında bulunduğu için hepsi için aynı tarihteki verileri değerlendirmek yanıltıcı olabileceğinden, daha sağlıklı bir değerlendirme yapabilmek için tüm ülkeleri hastalık açısından aynı zaman skalasında değerlendirmek gerekmektedir. Ayrıca devam etmekte olan pandemide açılanan vaka sayıları her ülkenin test yapma politikası ve/veya kapasitesine bağlı olarak çok farklılık gösterdiğinden; ülkelerin tespit etmesi daha kolay olan ve dolayısıyla nispeten hataya daha az açık olan, "COVID-19'dan kaynaklanan ölümler" esas parametre olarak kabul edildi ve bu parametre "ölüm/ milyon nüfus" olarak değerlendirilerek ülkeler arası normalizasyon elde edilmeye çalışıldı.

Bu bağlamda 21 Nisan 2020 tarihi itibariyle 250 veya daha fazla ölüm rapor eden 30 ülkeyi değerlendirmeye alarak istatistiksel bir karşılaştırma yaptık. Bu karşılaştırmada belirtilen seçim kriterlerine uyan 30 ülke halen ulusal BCG aşılama politikası uygulayan ve uygulamayan ülkeler olarak iki ana gruba ayrıldı (Tablo 1). Tüm bu ülkelerin raporladıkları COVID-19'a bağlı ölüm sayısının 100'e ulaştığı gün (üssel artışa geçiş) her ülke için 1. Gün olarak kabul edildi ve her bir ülke için bugünden itibaren 18 gün boyunca ölüm/milyon nüfus değerleri değerlendirmeye alındı (Şekil 2).

Şekil 2'de görüldüğü üzere 7. günden itibaren ulusal BCG aşısı uygulamayan ülkelerin ölüm oranının uygulayan ülkelerden istatistiksel olarak anlamlı bir şekilde daha yüksek olduğu gözükmektedir. Bu gözlem de halen devam etmekte olan salgında ulusal BCG aşılaması uygulamayan ülkelerin daha kötü sonuçlarla yüzleştiğini göstermektedir.

Tablo 1. Değerlendirmeye alınan 30 ülkenin 21 Nisan 2020 tarihinde rapor ettiği ölüm sayıları ve halen ulusal BCG aşısı uygulayıp uygulamamasına göre gruplandırılması

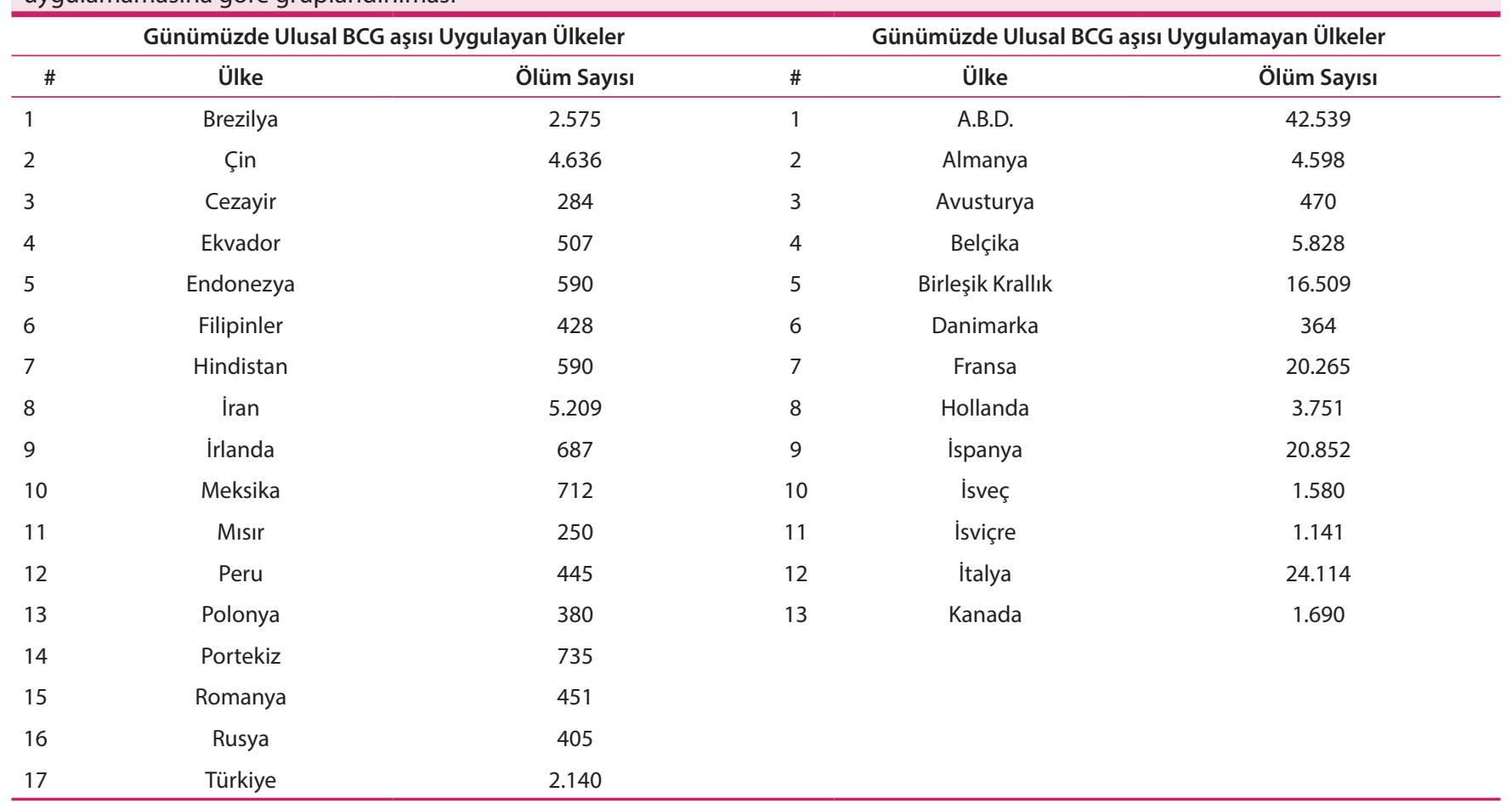

https://ourworldindata.org/grapher/total-deaths-and-cases-covid-19 


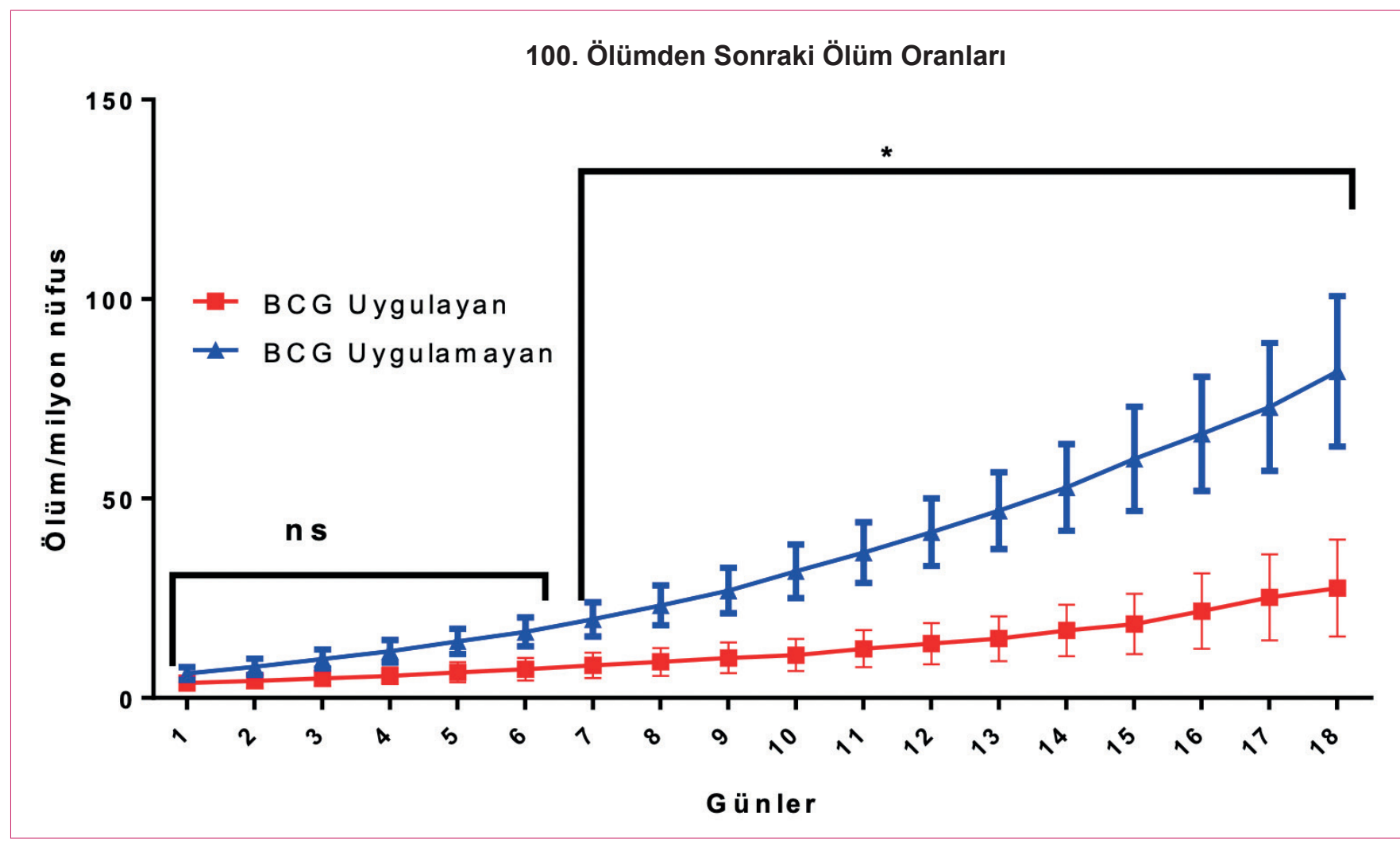

Şekil 2. Değerlendirmeye alınan 21 Nisan 2020 tarihinde 250 ve daha fazla ölüm rapor eden ülkelerin 100 . ölümden sonraki 18 gün boyunca ölüm/milyon nüfus değerleri. Kırmızı çizgi grafiği halen grafiği halen ulusal BCG aşı politikasını uygulayan 17 ülkenin günbegün ortalamasını (+/- ortalamanın standart hatası) gösterirken mavi çizgi grafiği günümüzde ulusal BCG aşısı uygulamayan ülkerin ortalamasını (+/- ortalamanın standart hatası) göstermektedir. Her bir gün kendi içinde iki taraflı Welch'in t-testi ile karşılaştırılmış ve $p<0.05\left({ }^{*}\right)$ anlamlı olarak kabul edilmiştir.

Her ne kadar ulusal BCG aşılama politikasını devam ettiren ülkelerde COVID-19 salgını daha iyi bir şekilde kontrol edilse de, bu ülkeler kendi aralarında da farklılık göstermektedir. Bu farklılıkları açıklamak için BCG aşılama programlarında kullanılan suşların ülkelere göre farklılık gösterdiğini göz önünde bulundurmak gerekir. BCG aşııı ilk kez 1921 yılında kullanıldı ve ilk çekirdek kültürler üretim için birçok ülkeye gönderildi. Kültürdeki seri pasajlamalar sırasında BCG suşlarının silinme, tek nükleotid polimorfizmi ve ikilenme gibi birçok genomik değişikliğe uğraması sonucu bir çok değişik alt suş oluştu. ${ }^{[12]}$ BCG aşıları art arda kopya varyantlarına (DU-2) göre dört gruba ayrılmaktadırlar DU2 Grup I ve II'de orijinal suşa genetik olarak daha yakın olan "erken” aşı suşları bulunmaktadır. Bunlara Rusya, Japonya ve Brezilya suşları örnek gösterilebilir. Diğer taraftan Pasteur, Danimarka ve Connaught gibi "geç" aşı suşlarını barındıran DU2-III ve IV grupları genetik olarak orijinal suşa daha uzaktır. ${ }^{[12]}$ Aş1 suşlarının kültürde büyüme karakteristikleri, biyokimyasal özellikleri, immunojenesiteleri ve virülansları farklılık göstermektedir. Geç BCG aşı suşları hücre duvarlarında sadece alfa ve beta mikolik asitleri bulundurup erken aşı suşlarının aksine metoksimikolik asit bulundurmazlar. ${ }^{[13]} \mathrm{Bu}$ farklılıkla tutarlı bir şekilde erken BCG aşı suşları ile aşılanmış çocuklarda canlı bakteriler mezenterik lenf düğümlerinde altı aya kadar kalabilirken, geç aşı suşları ile aşılanan çocuklarda canlı bakteri gözlemlenmemiştir. [14] Benzer bir şekilde metoksimikolat üretebilen erken aşı suşlarının geç suşlardan daha etkin bir immün uyarıcı olduğu bilinmektedir. ${ }^{[15]}$ Örneğin mikolik asitlerin doğal başıklık sistemi tetikleyicilerine tekrar maruz bırakılan makrofajların yüksek seviyelerde IFN- $\gamma$, myeloperoksidaz ve TNF- $\alpha$ üretmesine neden olduğu bilinmektedir. [16] $\mathrm{Bu}$ bulgular mikolik asitlerin eğitilmiş bağışıklı̆ğ tetikleyebilecek önemli bir ligand grubu olduğunu göstermektedir. $\mathrm{Bu}$ bağlamda, metoksimikolik asitlerin makrofajları aktifleştirdiği ve enflamatuar etkisi olduğu bilinirken, öbür yandan ketomikolik asitlerin alternatif makrofaj aktifleşmesini tetikleyerek anti-enflamatuar etkisi olduğu bilinmektedir. ${ }^{[17]} \mathrm{Bu}$ sebeplerle BCG aşı suşlarının kalıcılığının ve bağışıklık sistemini uyarıcı özelliklerinin farklı olmasından dolayı farklı suşların eğitilmiş bağışıklığı tetikleyebilme kapasitelerinin farklı olabileceği hipotezi öne sürülebilir. 


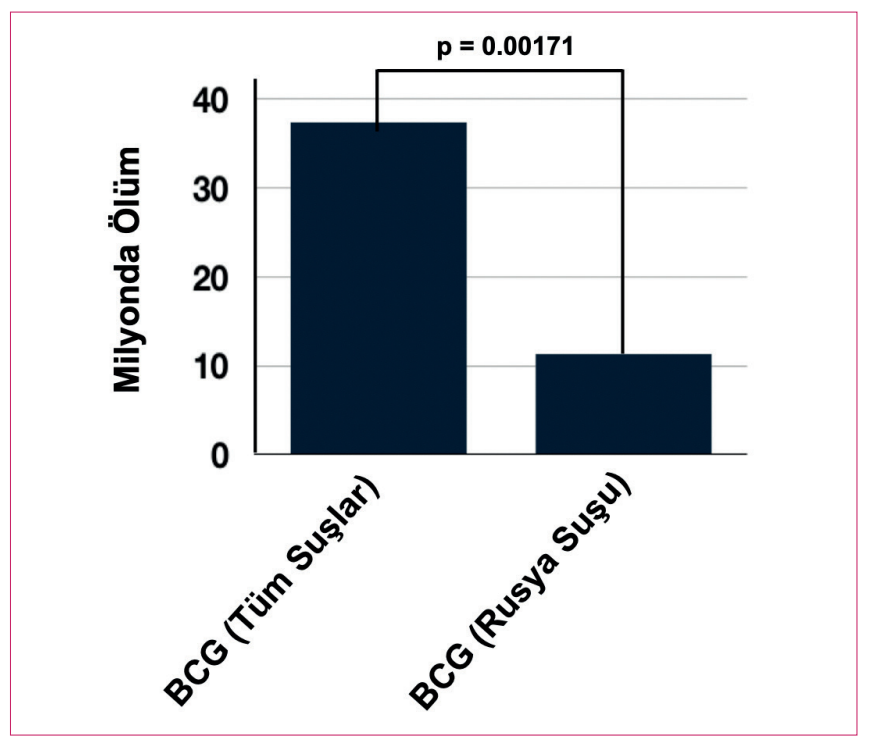

Şekil 3. Worldometer web sayfasından 26.04.2020 tarihli COVID-19 verileri indirildi. Ülke isimleri ve COVID-19 hastalığından ötürü vefat eden hasta sayıları 1 milyonluk nüfus oranına göre sabitlenmiş olarak düzenlendi. Dünyadaki BCG aşılama tiplerine göre ülke isimleri 2 ayrı gruba (BCG, BC Rusya olarak) ayrıldı. Her bir grubun aritmetik ortalaması, standart sapması ve alpha $=0.05$ bazlı güven aralıkları hesaplandı. Grup basına belirlenen ortalama değerleri kullanılarak yukarıdaki grafik çizildi. Standart sapma değerlerinin verinin dağınıklığından ötürü yüksek çıkması sebebiyle grafiğe eklenemedi. Gruplar arasında ikişerli olarak korelasyonlar hesaplandı. Bu hesaplamada kategorik (ülkelerin aşılama politikaları; BCG uygulayan ve BCG Rusya suşunu uygulayan) ve sayısal (1 milyonluk nüfus oranına göre sabitlenmiş vefat eden hasta sayıları) veri tipleri 'nokta çift seri bağıntısı' metoduyla (kor. test R fonksiyonu) analiz edildi. Gruplar arasında ikişerli olarak ortalama ölüm değerleri karşılaştırıldı. Bu karşılaştırmada grup içi örnek sayılarındaki farklılık ve verinin Normal dağılımdan sapması sebebiyle Welch t-testi (t.test $\mathrm{R}$ fonksiyonu) kullanıldı.
Farklı ülkelerde kullanılmış olan BCG aşı suşları incelendiğinde ${ }^{[18,19]}$ İran ve Çin'in kendi aşılarını üreten ülkeler olduğu görülmektedir. Bu ülkelerde kullanılan aşı suşları kesin olarak bilinmemekle beraber, İran'da kullanılan suş'un BCG-Pasteur 1173p2 olduğu ve Çin'de kullanılan suşun Glaxo 1077'den elde edildiğine dair bulgular vardır. Bu iki suşun özelliği Japonya ve Rusya suşlarına kıyasla çok daha fazla modifikasyona uğramış olmaları, yüksek derecede zayıflatılmış olmaları ve metoksimikolik asit üretememeleridir. ${ }^{[20,21]} \mathrm{Bu}$ nedenle İran ve Çin'de kullanılan BCG aşı suşlarının eğitilmiş bağışıklığı tetikleme kapasitelerinin çok daha yaygın kullanılan erken suşlardan çok daha düşük olabileceğini öne sürmek mümkündür.

İran ve Çin haricindeki bu çalışmada değerlendirmeye alınan ulusal aşılama politikasını günümüzde uygulayan diğer 15 ülke incelendiğinde ${ }^{[18,19]}$, düşük ölüm/milyon popülasyon değerleri gözlenen bir çok ülkenin birden fazla BCG suşu kullandığı (örn.; Cezayir, Meksika, Peru) görülmektedir. Bu ülkelerde hangi suşun etkisinin daha ağır bastığını söylemek mümkün olmadığından tek bir BCG suşu kullanılan ülkeler, suşların koruyuculukları arasındaki farklılıkları gözlemlemek için daha belirleyici olacaktır. Bu bağlamda bakıldığı zaman bu ülkeler arasında en yüksek ölüm oranı Portekiz ve İrlanda’da, en düşük ölüm oranları ise Polonya ve Brezilya'da gözlemlenmektedir (Şekil 4). Portekiz ve İrlanda'nın "geç" aşı suşlarından biri olan BCG Danimarka suşunu kullanırken, Polonya ve Brezilya ise "erken" aşı suşlarından biri olan Brezilya

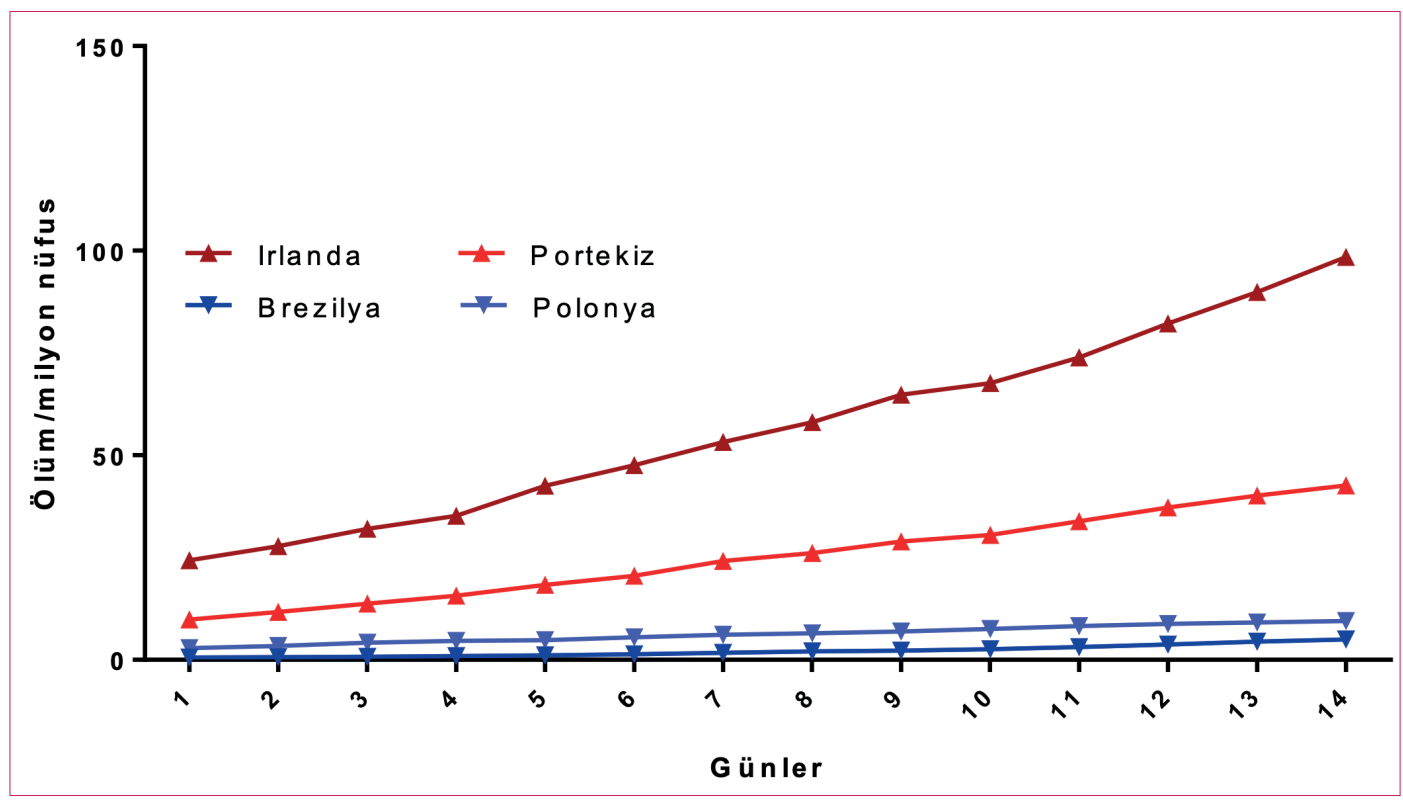

Şekil 4. Tek suş ile BCG aşılaması yapmakta olan ülkelerden dördünün 100 . ölümden sonraki 14 gün boyunca ölüm/milyon kişi değerleri. Kırmızı çizgiler Danimarka suşu kullanmakta olan ülkeleri, mavi çizgiler Brezilya suşunu kullanan ülkeleri göstermektedir. 
Tablo 2. 26 Nisan itibarıyla tüm BCG aşısı uygulayan ülkeler ile sadece Rusya suşunu uygulayan ülkelerin incelenmesinde yer alan ülke isimleri ve milyon nüfus başına düşen ölüm değerleri

\begin{tabular}{|c|c|c|c|}
\hline \multicolumn{2}{|c|}{ BCG Uygulayan Ülkeler } & \multicolumn{2}{|c|}{ BCG Rusya Suşu } \\
\hline Ülke İsmi & Ölüm /Milyon & Ülke İsmi & Ölüm /Milyon \\
\hline Andora & 518 & Panama & 37 \\
\hline İspanya & 490 & Ecuador & 33 \\
\hline İtalya & 436 & Turkey & 32 \\
\hline Fransa & 346 & North Macedonia & 28 \\
\hline Birleşik Krallık & 299 & $\begin{array}{l}\text { Dominican } \\
\text { Republic } \\
\end{array}$ & 25 \\
\hline Sint Maarten & 280 & Bulgaria & 8 \\
\hline Hollanda & 257 & Belarus & 7 \\
\hline İsveç & 217 & Russia & 5 \\
\hline İrlanda & 215 & Ukraine & 5 \\
\hline Adam Adası & 212 & Belize & 5 \\
\hline Kanal Adaları & 201 & Colombia & 5 \\
\hline Montserrat & 200 & Bolivia & 4 \\
\hline İsviçre & 185 & Uruguay & 4 \\
\hline Monako & 102 & Azerbaijan & 2 \\
\hline Portekiz & 86 & Cameroon & 2 \\
\hline Bermuda & 80 & Gabon & 1 \\
\hline Saint Martin & 78 & Paraguay & 1 \\
\hline Danimarka & 72 & Fildişi Sahilleri & 0,5 \\
\hline Kanada & 65 & & \\
\hline Slovenya & 39 & & \\
\hline Panama & 37 & & \\
\hline Norveç & 37 & & \\
\hline Martinik adası & 37 & & \\
\hline Estonya & 35 & & \\
\hline Finlandiya & 34 & & \\
\hline Ekvator & 33 & & \\
\hline Ingiliz Virgin Adaları & 33 & & \\
\hline Türkiye & 32 & & \\
\hline Romanya & 31 & & \\
\hline Antigua ve Barbuda & 31 & & \\
\hline Guadelupe & 30 & & \\
\hline İzlanda & 29 & & \\
\hline Kuzey Makedonya & 28 & & \\
\hline Bahama Adaları & 28 & & \\
\hline Macaristan & 27 & & \\
\hline Lihtenştayn & 26 & & \\
\hline Turks ve Caicos Adaları & 26 & & \\
\hline Dominik Cumhuriyeti & 25 & & \\
\hline Israil & 23 & & \\
\hline Moldova & 23 & & \\
\hline Peru & 21 & & \\
\hline Barbados & 21 & & \\
\hline Çekya & 20 & & \\
\hline Brezilya & 19 & & \\
\hline Aruba & 19 & & \\
\hline Sirbistan & 17 & & \\
\hline Bosna Hersek & 17 & & \\
\hline Lithuania & 15 & & \\
\hline Mayotte Adası & 15 & & \\
\hline Cayman Adaları & 15 & & \\
\hline Hırvatistan & 13 & & \\
\hline Yunanistan & 12 & & \\
\hline Güney Kıbrıs & 12 & & \\
\hline Meksika & 10 & & \\
\hline Cezayir & 10 & & \\
\hline Karadağ & 10 & & \\
\hline Ermenistan & 9 & & \\
\hline Arnavutluk & 9 & & \\
\hline Malta & 9 & & \\
\hline Bulgaristan & 8 & & \\
\hline Birleşik Arap Emirlikleri & 7 & & \\
\hline Belarus & 7 & & \\
\hline Mauritius & 7 & & \\
\hline Curaçao & 6 & & \\
\hline Letonya & 6 & & \\
\hline Honduras & 6 & & \\
\hline Trinidad ve Tobago & 6 & & \\
\hline Rusya & 5 & & \\
\hline Kolombiya & 5 & & \\
\hline Güney Kore & 5 & & \\
\hline Ukrayna & 5 & & \\
\hline Filipinler & 5 & & \\
\hline
\end{tabular}

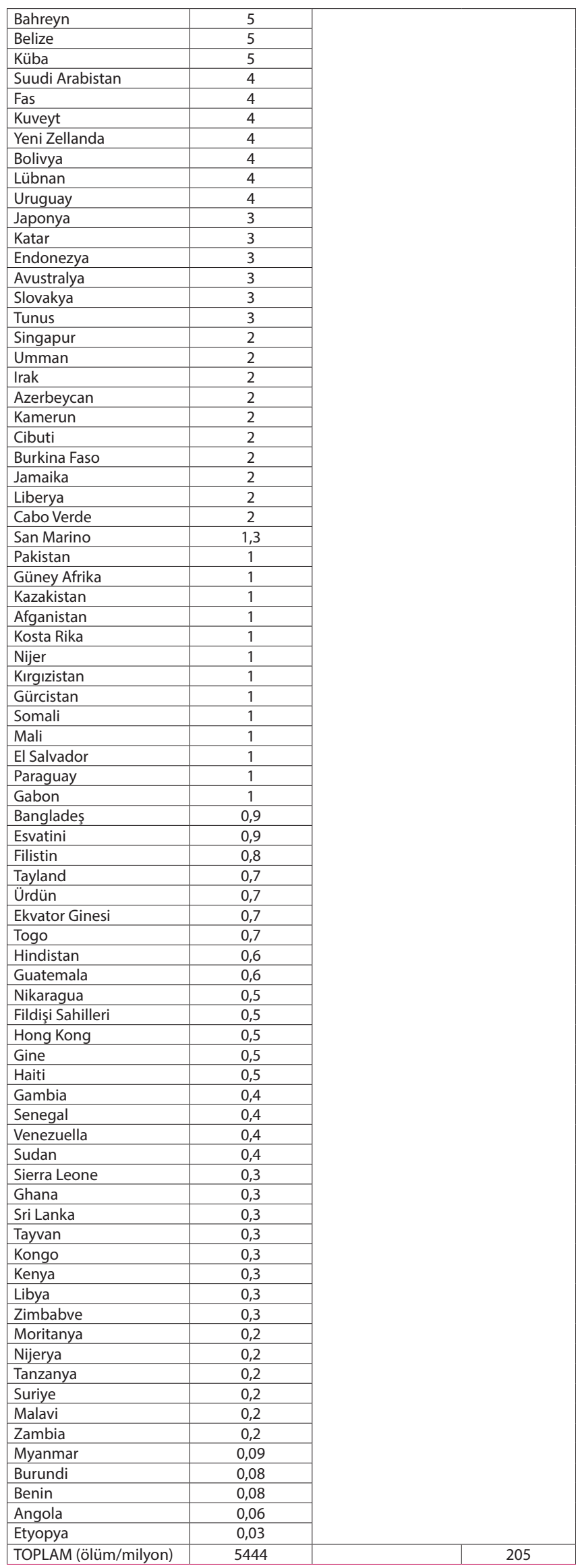


suşunu kullanması ilginçtir. ${ }^{[18,19]}$ Bu gözlem de "erken" aşı suşlarının eğitilmiş bağışıklığı tetikleyebilme kapasitesinin daha yüksek olabileceğini göstermektedir. Bir başka analiz ile de ülkemizin de kullandığı Rusya suşunun durumunu değerlendirdik. BCG kullanan ülkeler arasında (148 ülke), 18 ülkede Rusya suşunun kullanıldığı bildirilmektedir (Tablo 2). Bu ülkelerdeki milyon popülasyonda oluşan ölümleri karşılaştırdığımızda (Şekil 3), Rusya suşunun kullanıldığı ülkelerde daha az bir ölüm oranı gözlemlendiği anlaşılmaktadır. Şekil 3'teki verilere göre milyon kişideki ölüm ortalaması yaklaşık 38 iken Rusya suşunun kullanıldığı ülkelerde bu değer 11 olarak görülmektedir ( $\mathrm{p}=0,00171)$.

Tüm bu bilgiler ışığında salgının başlangıç noktası olan Çin ile çok geniş seyahat ve ticaret ağlarına sahip Asya ve Afrika ülkelerinde vaka sayısının beklenenin çok altında olmasının nedenlerinden bir tanesinin BCG aşılamasının sağladığı heterolog spesifik olmayan koruma olabileceği hipotezini öne sürmekteyiz. $\mathrm{Bu}$ hipotezin geçerliliğini test etmek sadece pandeminin süresi boyunca BCG ile aşılanmış ve aşılanmamış popülasyonların epidemiyolojik verilerini karşılaştırmak ile mümkündür. Pandemi süresince bu hipotezin aksine gelişmeler olmaz ise hipotezin geçerliliğinin hayat kurtaracak yankıları olması mümkündür. BCG aşısının uygulandığı yaşlı insanlarda bile akut solunum yolu enfeksiyonlarını engellediği bilindiğinden ${ }^{[6]}$, spesifik bir aşı geliştirilene kadar SARS-CoV-2 enfeksiyonuna yakalanma riski yüksek insanlara özellikle "erken" BCG aşı suşlarından birisi uygulanabilir. Bu yaklaşım özellikle ilk basamak sağlık çalışanları için de faydalı olabilir.

Peer-review: Externally peer-reviewed.

Authorship Contributions: Concept: MG; Design: MG, IG; Data Collection or Processing: MG, IG, ICA, EMI, ICY, VY; Analysis or Interpretation: MG, IG, ICA, EMI, ICY, VY; Literature Search: MG, IG, ICA, EMI, ICY, VY; Writing: MG, IG, ICA, VY; Critical Review: MG, IG, ICA, EMI, ICY, VY.

Conflicts of Interest: None

Funding Information: None

\section{Hakem Değerlendirmesi: Dış Bağımsız}

Yazarlık Katkısı: Fikir: MG; Tasarım: MG, IG; Veri Toplama ve işleme:çMG, IG, ICA, EMI, ICY, VY; Analiz/Norum: MG, IG, ICA, EMI, ICY, VY; Literatür Tarama: MG, IG, ICA, EMI, ICY, VY; Yazıyı yazan: MG, IG, ICA, VY; Eleştirel Değerlendirme: MG, IG, ICA, EMI, ICY, VY

Çıkar çatışması: Yoktur

Finansal destek: Kullanılmamıştır.

\section{Kaynaklar}

1. http://www.euro.who.int/en/health-topics/health-emergencies/ coronavirus-covid-19/statements/statement-we-can-beat-covid19-virus-through-solidarity
2. Aaby P, Kollmann T, Benn C. Nonspecific effects of neonatal and infant vaccination: public-health, immunological and conceptual challenges. Nat Immunol 2014;15:895-9. [Crossref]

3. Roth A, Gustafson P, Nhaga A, Djana Q, Poulsen A, Garly ML, et al. BCG vaccination scar associated with better childhood survival in Guinea-Bissau. Int J Epidemiol 2005;34:540-7. [Crossref]

4. Hollm-Delgado MG, Stuart EA, Black RE. Acute lower respiratory infection among Bacille Calmette-Guérin (BCG)vaccinated children. Pediatrics 2014;133:e73-81. [Crossref]

5. de Castro MJ, Pardo-Seco J, Martinón-Torres F. Nonspecific (Heterologous) Protection of Neonatal BCG Vaccination Against Hospitalization Due to Respiratory Infection and Sepsis. Clin Infect Dis 2015;60:1611-9. [Crossref]

6. Wardhana, Datau EA, Sultana A, Mandang VV, Jim E. The efficacy of Bacillus Calmette-Guerin vaccinations for the prevention of acute upper respiratory tract infection in the elderly. Acta Med Indones 2011;43:185e90. http://www.inaactamedica. org/archives/2011/21979284.pdf

7. Higgins JPT, Soares-Weiser K, Reingold A. Systematic review of the non-specific effects of BCG, DTP and measles containing vaccines. 2014. https://www.who.int/immunization/sage/ meetings/2014/april/3_NSE_Epidemiology_review_Report_to_ SAGE_14_Mar_FINAL.pdf

8. Jensen KJ, Larsen N, Biering-Sorensen S, Andersen A, Eriksen H B, Monteiro I, et al. Heterologous immunological effects of early BCG vaccination in low-birth-weight infants in Guinea-Bissau: a randomized controlled trial. J Infect Dis 2015;211:956-67. [Crossref]

9. Netea MG, Quintin J, van der Meer JW. Trained immunity: a memory for innate host defense. Cell Host Microbe 2011;9:35561. [Crossref]

10. Moorlag SJCFM, Arts RJW, van Crevel R, Netea MG. Nonspecific effects of BCG vaccine on viral infections. Clin Microbiol Infect 2019;25:1473-8. [Crossref]

11. Arts RJW, Moorlag SJCFM, Novakovic B, Li Y, Wang SY, Oosting M, et al. BCG Vaccination Protects against Experimental Viral Infection in Humans through the Induction of Cytokines Associated with Trained Immunity. Cell Host Microbe 2018;23:89-100.e5. [Crossref]

12. Brosch R, Gordon SV, Garnier T, Eiglmeier K, Frigui W, Valenti P, et al. Genome plasticity of BCG and impact on vaccine efficacy. Proc Natl Acad Sci U S A 2007;104:5596-601. [Crossref]

13. Behr MA, Schroeder BG, Brinkman JN, Slayden RA, Barry CE 3rd. A point mutation in the mma3 gene is responsible for impaired methoxymycolic acid production in Mycobacterium bovis BCG strains obtained after 1927. J Bacteriol 2000182:33949. [Crossref]

14. Zeyland J, Piasecka-Zeyland E. Sur la vitalité du BCG dans l'organisme vacciné. Ann Inst Pasteur 1936;56:46-51.

15. Hayashi D, Takii T, Fujiwara N, Fujita Y, Yano I, Yamamoto S, et al. Comparable studies of immunostimulating activities in vitro among Mycobacterium bovis bacillus Calmette-Guérin (BCG) substrains. FEMS Immunol Med Microbiol 2009;56:116-28. [Crossref]

16. Korf J, Stoltz A, Verschoor J, De Baetselier P, Grooten J. The Mycobacterium tuberculosis cell wall component mycolic acid elicits pathogen-associated host innate immune responses. Eur J Immunol 2005;35:890-900. [Crossref] 
17. Beken SV, Al Dulayymi JR, Naessens T, Koza G, Maza-Iglesias $\mathrm{M}$, Rowles R, et al. Molecular structure of the Mycobacterium tuberculosis virulence factor, mycolic acid, determines the elicited inflammatory pattern. Eur J Immunol 2011;41:450-60. [Crossref]

18. Ritz N, Curtis N. Mapping the global use of different BCG vaccine strains. Tuberculosis (Edinb) 2009;89:248-51. [Crossref]

19. Zwerling A, Behr MA, Verma A, Brewer TF, Menzies D, Pai M. The BCG World Atlas: a database of global BCG vaccination policies and practices. PLoS Med 2011;8:e1001012. [Crossref]
20. Fallah F, Nasiri MJ, Pormohammad A. Bacillus Calmette-Guerin (BCG) vaccine in Iran. J Clin Tuberc Other Mycobact Dis 2018;11:22. [Crossref]

21. Hu Y, Chen Y, Liang H, Wang Y. An Overview of Coverage of BCG Vaccination and Its Determinants Based on Data from the Coverage Survey in Zhejiang Province. Int J Environ Res Public Health 2018;15:1155. [Crossref] 